\title{
The effect of long-term calcium supplementation on indices of iron, zinc and magnesium status in lactating Gambian women
}

\author{
BY LIYA YAN, ANN PRENTICE*, BAKARY DIBBA, LANDING M. A. JARJOU \\ AND DOROTHY M. STIRLING \\ Medical Research Council Dunn Nutrition Unit, Downhams Lane, Milton Road, \\ Cambridge CB4 $1 X J$ and Keneba, PO Box 273, The Gambia
}

AND SUSAN FAIRWEATHER-TAIT

Institute of Food Research, Norwich Laboratory, Norwich Research Park, Colney, Norwich NR4 7UA

(Received 15 September 1995 - Revised 3 May 1996-Accepted 15 May 1996)

\begin{abstract}
The effect of long-term supplementation with $\mathrm{CaCO}_{3}$ on indices of $\mathrm{Fe}, \mathrm{Zn}$ and $\mathrm{Mg}$ status was investigated in a randomized, double-blind intervention study of sixty lactating Gambian women. The supplement contained $1000 \mathrm{mg} \mathrm{Ca}$ and was consumed between meals $5 \mathrm{~d} /$ week, for 1 year starting 1.5 weeks postpartum. Compliance was $100 \%$. Plasma ferritin concentration, plasma $\mathrm{Zn}$ concentration and urinary $\mathrm{Mg}$ output were measured before, during and after supplementation at 1.5, 13, 52 and 78 weeks postpartum. No significant differences in mineral status were observed at any time between women in the supplement and placebo groups. Analysis of the longitudinal data series showed that plasma ferritin and Mg excretion were characteristic of the indivdiual $(P<0 \cdot 001)$. Within individuals, ferritin concentration was higher at 1.5 weeks postpartum than later in lactation $(P=0.002)$. Plasma $\mathrm{Zn}$ concentration was lower at 1.5 weeks postpartum than at other times $(P<0.001)$, an effect which disappeared after albumin correction. Low plasma concentrations of ferritin and $\mathrm{Zn}$ indicated that the Gambian women were at high risk of Fe and $\mathrm{Zn}$ deficiency. Measurements of $\alpha_{1}$-antichymotrypsin suggested that the results were not confounded by acute-phase responses. The results of the present study indicate that $1000 \mathrm{mg} \mathrm{Ca}$ as $\mathrm{CaCO}_{3}$ given between meals does not deleteriously affect plasma ferritin and $\mathrm{Zn}$ concentrations or urinary $\mathrm{Mg}$ excretion in women who are at risk of $\mathrm{Fe}$ and $\mathrm{Zn}$ deficiency.
\end{abstract}

Calcium: Mineral interactions: Lactation

High intakes of $\mathrm{Ca}$ have been associated with a decreased risk of osteoporosis, hypertension, pre-eclampsia, hypercholesterolaemia, diabetes mellitus and certain cancers (Levenson \& Bockman, 1994). The use of Ca supplements is an increasingly popular method of increasing dietary intake, and in the USA, for example, total annual sales exceed $\$ 200$ million per annum (Gossel, 1991; Levenson \& Bockman, 1994). There is evidence suggesting that $\mathrm{Ca}$ absorption may be greater and more consistent if supplements are consumed with food rather than in the fasting state (Heaney, 1991; Levenson \& Bockman, 1994), and frequently advice is given to ingest Ca supplements at meal-times (Levenson \& Bockman, 1994). However, it has long been recognized that high Ca intakes may adversely affect the absorption and status of other minerals, especially Fe (Hallberg et al. 1992) and Zn (Argiratos \& Samman, 1994). This is a potential concern, especially for individuals who are at risk of becoming deficient in these minerals. From the evidence available the effect appears to be related to mineral interactions in the lumen of the gastrointestinal tract or to competition between minerals for absorptive pathways (Fairweather-Tait, 1995). One

$$
\text { * For reprints. }
$$


possible strategy to minimize mineral interactions while avoiding potential problems associated with the fasting state would be to consume $\mathrm{Ca}$ supplements between meals. However, the effects of $\mathrm{Ca}$ supplements consumed in this way on the status of other minerals has been little studied (Whiting, 1995).

An opportunity arose during a detailed investigation of $\mathrm{Ca}$ requirements of lactating women (Prentice et al. 1995) to examine whether the long-term, regular ingestion of a $\mathrm{CaCO}_{3}$ supplement affects $\mathrm{Fe}, \mathrm{Zn}$ and $\mathrm{Mg}$ status, when consumed between the mid-day and evening meals. Sixty Gambian mothers took part in a randomized, double-blind, placebocontrolled, supplementation study during prolonged lactation. The supplement, $1000 \mathrm{mg} \mathrm{Ca}$ as $\mathrm{CaCO}_{3}$, or placebo was consumed daily on $5 \mathrm{~d} /$ week for 12 months. The aim of the work reported here was to study the effect of the Ca supplement on plasma $\mathrm{Zn}$ and ferritin concentrations and on urinary $\mathbf{M g}$ excretion during and after the supplementation period.

\section{SUBJECTS AND METHODS}

Subjects and study design

Sixty lactating mothers were enrolled in the study between March 1990 and March 1991. The mothers were resident in Keneba and Manduar, two villages in a rural region of The Gambia, West Africa, and were 16-41 years old (mean 28 (SD 8) years), parity 1-13 (mean 5 (SD 3)). The women breast-fed their infants, fully and on demand, for more than 18 months, as is traditional in this society, with the provision of complementary foods from about 3-4 months. The study was approved by the MRC Gambia Ethics Committee and informed consent was obtained from all subjects.

All the women were taking part in a detailed longitudinal investigation of $\mathrm{Ca}$ requirements of lactating women habituated to a low-Ca diet (Prentice et al. 1995). The aim of the larger study was to determine, by means of a randomized, placebo-controlled trial, the effect of $\mathrm{Ca}$ supplementation on bone mineralization, lactational performance and efficiency of $\mathrm{Ca}$ absorption in lactating women accustomed to a low dietary $\mathrm{Ca}$ intake $(7 \cdot 1 \mathrm{mmol} / \mathrm{d}(283 \mathrm{mg} / \mathrm{d})$; Fairweather-Tait et al. 1995; Prentice et al. 1995). Baseline measurements were made on 9 (SD 1) d postpartum. On the following day the women were randomly assigned, double-blind, to either a Ca-supplement or placebo-control group. Since baseline measurements were made on approximately four subjects each month, a permuted block of four was used for the group allocation to minimize the possibility of seasonal bias.

The supplements, consisting either of two chewable $\mathrm{CaCO}_{3}$ tablets (Calcichew; Shire Pharmaceuticals Ltd, Andover, Hants; $12.5 \mathrm{mmol}$ (500 mg) elemental Ca per tablet) or two tablets of dextrose of similar taste and texture (Dextro-energy; CPC Ltd, Esher, Surrey), were provided $5 \mathrm{~d} /$ week for the subsequent 12 months. The tablets were delivered to the subjects each day by fieldworkers who supervised their consumption. The supplements were consumed in the early evening between 17.00 and 19.00 hours. They were taken at least $2 \mathrm{~h}$ after lunch (generally eaten at 14.00-15.00 hours) and at least $1 \mathrm{~h}$ before dinner (eaten about 20.00 hours). During the fast month of Ramadan, tablets were consumed later in the evening once the subjects had broken fast but before their main meal. Tablets missed because of illness or absence from the village were taken at weekends. Over the total supplementation period, compliance was $100 \%$ (i.e. every subject consumed all the tablets that had been allocated to her, supervised by the fieldworker) and the Ca intake of the supplemented group was raised by an average of $17.9 \mathrm{mmol} / \mathrm{d}(714 \mathrm{mg} / \mathrm{d})$.

There were no differences between women in the supplement $(\mathrm{S})$ and placebo $(\mathrm{P})$ groups in terms of age (years; S 28 (SD 7), P 28 (SD 8)), parity (S 5 (SD 3), P 6 (SD 3)), weight at baseline (kg; S 53.9 (SD 5.7), P 55.9 (SD 8.9)), height (m; S 1.59 (SD 0.05), P 1.60 (SD 0.06)), 
or dietary Ca intake at 13 weeks (mmol/d; S 6.9 (SD 2.9), P 7.2 (SD 3.2)). Further details of the subjects and the supplementation study are described elsewhere (Prentice et al. 1995).

Plasma and urine for the assessment of $\mathrm{Zn}, \mathrm{Fe}$ and $\mathrm{Mg}$ status were obtained at baseline and at 13, 52 and 78 weeks postpartum (d ; mean 92 (SD 6), 366 (SD 5) and 547 (SD 5)). Blood from the antecubital vein was collected after an overnight fast into cooled lithium heparin tubes, centrifuged within $45 \mathrm{~min}$, the plasma separated and stored at $-20^{\circ}$. Urine was collected over a $24 \mathrm{~h}$ period. All urine containers and apparatus were acid-washed to minimize mineral contamination. A fieldworker visited the subject at the start and end of the collection period, and at regular intervals during the day to collect filled urine bottles and to deliver them to the laboratory refrigerator. The urine fractions for each subject were pooled, mixed, and the total volume recorded. The portion for $\mathrm{Mg}$ analysis was acidified with concentrated $\mathrm{HCl}$ (Spectrosol; $\mathrm{BDH}$, Poole, Dorset) to a final concentration of $0 \cdot 12 \mathrm{~mol} / 1(10 \mathrm{ml} / \mathrm{l})$ and stored at $-20^{\circ}$. The plasma and urine samples were transported to the Cambridge laboratory on dry ice for analysis.

\section{Laboratory assays}

Plasma ferritin was measured by ELISA using a modification of a published method (Anderson \& Kelly, 1981). The modifications were: diluting rabbit antiferritin antibody 1:400 with coating buffer, diluting the antibody-horseradish peroxidase (EC 1.11.1.7) conjugate $1: 15000$ with bovine serum albumin, diluting the ferritin standards with bovine serum albumin. Antisera and human liver ferritin standards were obtained from Dako Ltd, High Wycombe, Bucks. Bovine serum albumin, fraction V, was purchased from Sigma Chemicals Ltd, Poole, Dorset. The lower limit of the reference range for plasma ferritin was taken as $12 \mu \mathrm{g} / 1$ (Fairweather-Tait, 1993).

Plasma Zn was measured colorimetrically using a commercial kit method (Wako Chemicals GmbH, Nauss, Germany) with a Cobas-Bio centrifugal analyser (Roche Products Ltd, Welwyn Garden City, Herts.). The method is based on the formation of a coloured complex between $\mathrm{Zn}$ and '5-Br-PAPS' (2-(5-bromo-2-pyridylazo)-5-( $N$-propyl$N$-sulphopropylamino)-phenol) and salicylaldoxime, after deproteinization with trichloracetic acid. This assay was evaluated against flame atomic absorption spectroscopy and the two methods were found to be in close agreement.

Urinary $\mathrm{Mg}$ concentrations were measured with the Cobas-Bio centrifugal analyser using an enzymic method (Tsang et al. 1988). Reagents were purchased from Sigma Chemicals Ltd and the $\mathrm{Mg}\left(\mathrm{NO}_{3}\right)_{2}$ standard from BDH Ltd, Poole, Dorset. The assay was linear below $0.82 \mathrm{mmol} / 1(20 \mathrm{mg} / \mathrm{l})$. Samples and standards were diluted as necessary with $\mathrm{HCl}(0.12 \mathrm{~mol} / 1 ; 10 \mathrm{ml} / 1$; Spectrosol, BDH Ltd $)$.

The plasma proteins albumin and $\alpha_{1}$-antichymotrypsin were measured by immunonephelometric methods with the Cobas-Bio centrifugal analyser using specific antisera, calibrators and reagents purchased from Dako Ltd. The $\alpha_{1}$-antichymotrypsin assays were conducted on the samples collected at 13 weeks only. The upper limit of the reference range for $\alpha_{1}$-antichymotrypsin concentration, an acute-phase marker, was taken as $0.64 \mathrm{~g} / 1$ (Calvin et al. 1988).

Creatinine concentration was measured in plasma and urine to determine creatinine clearance rate. The samples were assayed using a commercial centrifugal analyser kit based on the kinetic buffered Jaffé reaction without deproteinization (Roche Products Ltd). A creatinine clearance rate of $<60 \mathrm{ml} / \mathrm{min}$ per $1.73 \mathrm{~m}^{2}$ was taken as an indication of incomplete urine collection (Prentice et al. 1995). Rates below this threshold were obtained for two, four and twelve subjects at 13,52 and 78 weeks respectively, and the daily $\mathrm{Mg}$ outputs for these subjects were omitted from final data analysis.

Reference quality-control materials were included with all batches of analyses to monitor 
accuracy and precision. The materials used were: plasma Zn, Certified Reference Human Serum (J. Versieck, University of Ghent, Belgium); plasma ferritin, Lyphocheck Immunoassay Control (Bio-Rad Laboratories Ltd, Hemel Hempstead, Herts.); urinary Mg and creatinine, Lyphocheck Normal Urine Control (Bio-Rad Laboratories Ltd); plasma creatinine, Roche Control Serum N (Roche Products Ltd); plasma albumin, Seronorm Protein (Nycomed Pharma A/S, Oslo, Norway); plasma $\alpha_{1}$-antichymotrypsin, Human Serum Protein Control (Dako Ltd). Observed values for all reference materials were within the quoted ranges provided by the producers. Measurements of between-batch reproducibility were $3 \%$ (at $12 \mu \mathrm{mol} / 1$ ), $5 \%$ (at $30 \mu \mathrm{g} / \mathrm{l}$ ) and $2 \%$ (at $4 \mathrm{mmol} / \mathrm{l}$ ) for the $\mathrm{Zn}$, ferritin and $\mathrm{Mg}$ assays respectively. Staff conducting the laboratory analyses in Cambridge were blind to the treatment-group assignments.

\section{Comparative data}

Comparative data were obtained at 13 weeks postpartum (88 (SD 8) d) from fifteen lactating British women living in Norwich, Norfolk (Prentice et al. 1995). These women were 22-41 years old, parity 1-4 (age 29 (SD 5) years, parity 2 (SD 1)). Eight mothers were exclusively breast-feeding, seven were also providing their infants with small quantities of formula milk, other drinks or solid foods. The mothers were heavier and taller than the Gambian subjects (weight 64.6 (SD 11.0) kg; height 1.64 (SD 0.06) m). Identical techniques were used for the collection of plasma and urine as in the Gambian study, and the samples were analysed alongside the Gambian samples.

\section{Statistical analysis}

Statistical analyses were performed by ANOVA (repeat measures, nested form), analysis of covariance and linear regression using Linear Model software on DataDesk 4.1 (Data Description Inc., 1993). The Data Desk approach is suitable for use with unbalanced datasets; missing datapoints are excluded from analyses. Scheffé post hoc tests were used to test the significance of differences between groups of data. Analyses of plasma ferritin results were conducted after logarithmic transformation to correct a marked positive skew in the distibution. Possible seasonal effects were explored by dividing each year into three seasons: wet (July-October), harvest (November-February) and hot (March-June).

Exploration of possible effects of the supplement were examined in two ways. First, by constructing a model using the measure of interest at either 13,52 or 78 weeks as dependent variable, with its value at baseline, season and supplementation group as independent variables. Second, by constructing a model with the measure of interest as dependent variable and with subject, supplementation group, lactation stage and season as independent variables. The first approach investigates differences between women in the $\mathbf{S}$ and $\mathbf{P}$ groups at each lactation stage, after adjusting for initial value and season. The second approach examines the possible effect of the supplement on time trends within subjects. Group differences observed with both methods, examined using the Scheffé post hoc test, are presented as means and $95 \% \mathrm{CI}$.

\section{RESULTS}

No significant differences were observed at any time in the indices used to assess $\mathrm{Zn}, \mathrm{Fe}$ and $\mathrm{Mg}$ status between women receiving the $\mathrm{Ca}$ supplement and those receiving the placebo (Tables 1 and 2). The observed mean differences were small, generally $<10 \%$ of the total value (Table 2). The two statistical approaches used to examine the effect of the supplement gave similar results (Table 2). In addition, there was no significant difference in plasma albumin between the groups (Table 1).

Concentrations of the acute-phase marker, $\alpha_{1}$-antichymotrypsin, measured at the 13 weeks time point, were similar for women in the $S$ and $P$ groups and no subject had a 


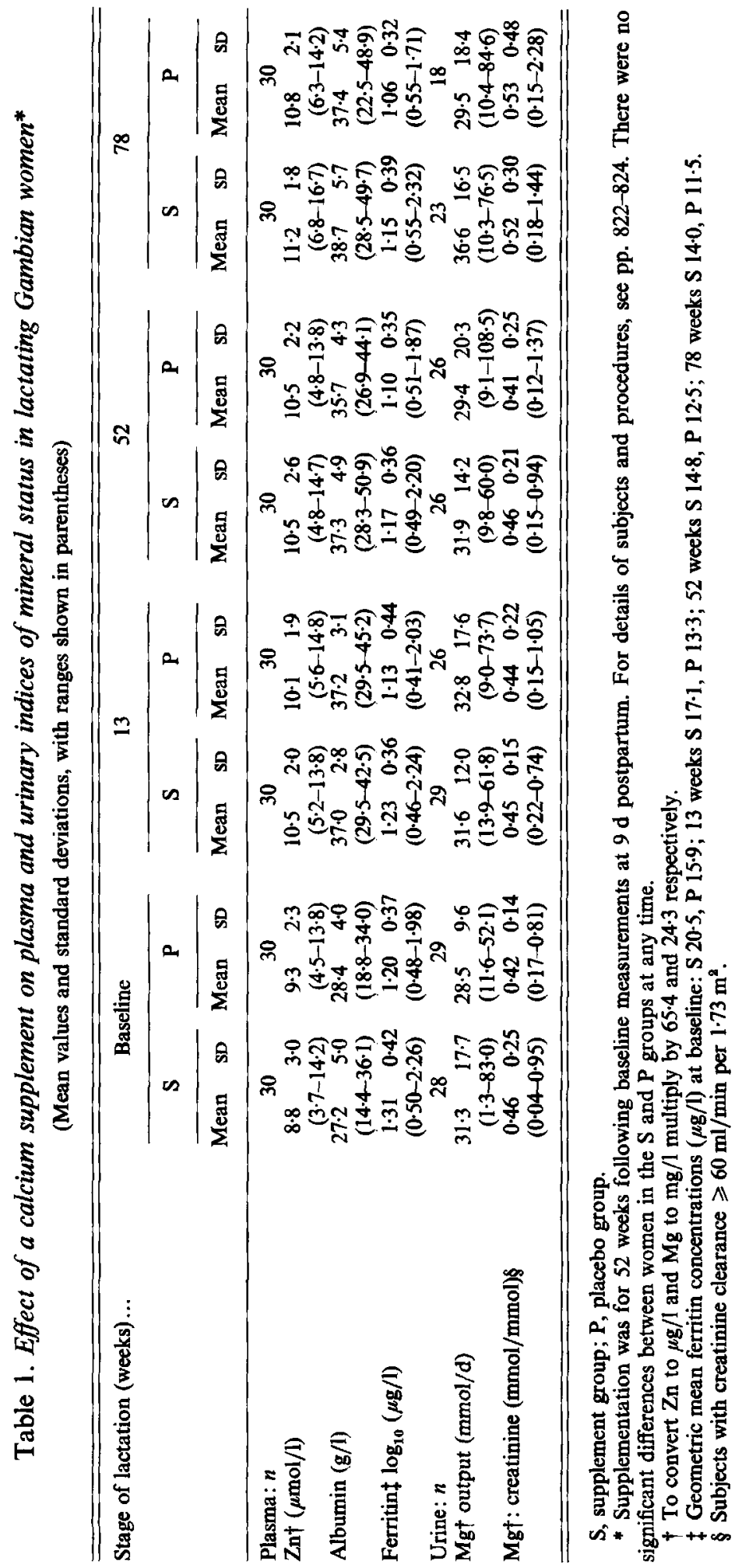


Table 2. Differences between calcium-supplemented $(S)$ and placebo $(P)$ groups of lactating Gambian women in plasma and urinary indices of mineral status after statistical adjustment*

(Values are mean differences $\mathrm{S}-\mathrm{P}$ and $95 \% \mathrm{CI}$ for sixty subjects)

\begin{tabular}{|c|c|c|c|c|}
\hline & $\begin{array}{c}\text { Plasma Zn } \\
(\mu \mathrm{mol} / 1)\end{array}$ & $\begin{array}{l}\text { Plasma ferritin } \\
\left(\log _{10} ; \mu \mathrm{g} / 1\right)\end{array}$ & $\begin{array}{l}\text { Plasma ferritin } \dagger \\
\quad\left(\log _{10} ; \mu \mathrm{g} / 1\right)\end{array}$ & $\begin{array}{c}\text { Urinary Mg } \\
(\mathrm{mmol} / \mathrm{d})\end{array}$ \\
\hline \multicolumn{5}{|l|}{ Model 1} \\
\hline 13 weeks & $\begin{array}{c}+0.6 \\
(-0.5-+1.7)\end{array}$ & $\begin{array}{c}+0.04 \\
(-0.13-+0.21)\end{array}$ & $\begin{array}{c}-0.01 \\
(-0.18-0.16)\end{array}$ & $\begin{array}{c}-2 \cdot 4 \\
(-10 \cdot 4-5 \cdot 6)\end{array}$ \\
\hline 52 weeks & $\begin{array}{c}+0.4 \\
(-0.7-+1.5)\end{array}$ & $\begin{array}{c}+0.02 \\
(-0.13-+0.17)\end{array}$ & $\begin{array}{c}-0.05 \\
(-0.22-+0.12)\end{array}$ & $\begin{array}{c}+1 \cdot 2 \\
(-8 \cdot 6-+11 \cdot 0)\end{array}$ \\
\hline 78 weeks & $\begin{array}{c}+0-4 \\
(-0.6-+1 \cdot 4)\end{array}$ & $\begin{array}{c}+0.04 \\
(-0.12-+0.20)\end{array}$ & $\begin{array}{c}+0-02 \\
(-0.15-+0.19)\end{array}$ & $\begin{array}{c}+8 \cdot 7 \\
(-1 \cdot 1-+18 \cdot 5)\end{array}$ \\
\hline \multicolumn{5}{|l|}{ Model 2} \\
\hline All time points & $\begin{array}{c}+0.1 \\
(-0.5-+0.7)\end{array}$ & $\begin{array}{c}+0.09 \\
(-0.08-+0.26)\end{array}$ & $\begin{array}{c}+0.02 \\
(-0.13-+0.17)\end{array}$ & $\begin{array}{c}+2 \cdot 8 \\
(-2 \cdot 4-+8 \cdot 0)\end{array}$ \\
\hline
\end{tabular}

Model 1; effect of $S$ group on the measured variable at each time point after adjusting for baseline value and season using analysis of covariance; model 2; effect of $S$ group on the measured variable after adjusting for subject, season and lactation stage using repeat measures analysis of variance (nested form).

* Supplementation was for 52 weeks following baseline measurements at $9 \mathrm{~d}$ postpartum. For details of subjects and procedures, see pp. 822-824. No difference was statistically significantly different from $0(P>0-05)$.

$\dagger$ Subjects with plasma ferritin concentration $\geqslant 12 \mu \mathrm{g} / 1$ at all time points, $n 30$.

concentration above the reference range. The mean values in the two groups were: supplemented 0.35 (SD 0.06, range $0.26-0.56$ ) $\mathrm{g} / \mathrm{l}$; placebo 0.33 (SD 0.006, range $0.22-0.52) \mathrm{g} / 1$.

A substantial proportion of Gambian mothers had a plasma ferritin concentration below $12 \mu \mathrm{g} / \mathrm{l}$, indicating depleted $\mathrm{Fe}$ stores. The percentage of subjects with low ferritin concentrations was 33 at baseline, 43 at 13 weeks, 44 at 52 weeks and 50 at 78 weeks. No effect of the Ca supplement on plasma ferritin was observed if the data were restricted to mothers with plasma ferritin concentrations above $12 \mu \mathrm{g} / 1$ (Table 2).

In the longitudinal dataset, plasma ferritin concentration and urinary $\mathrm{Mg}$ excretion were characteristic of the individual across the four time points, but this was not observed for plasma $\mathrm{Zn}$ and albumin concentrations (ferritin $P<0.001, \mathrm{Mg}$ output, $P<0.001$, $\mathrm{Mg}$ : creatinine $P<0.001, \mathrm{Zn} P=0.08$, albumin $P=0.21$ ). Within individuals there were highly significant effects of stage of lactation, with plasma $\mathrm{Zn}$ and albumin concentrations being $15 \%$ lower at day 9 than later in lactation $(P<0.001)$, and plasma ferritin levels being $10 \%$ higher $(P=0.002)$. For example, the mean differences within individuals between measurements at 52 weeks compared with those at baseline were: ferritin -0.13 $(95 \%$ CI $\left.-0.21--0.05) \mu \mathrm{g} / \log _{10}\right), \mathrm{Zn}+1.5(95 \% \mathrm{CI}+0.7-+2.3) \mu \mathrm{mol} / \mathrm{l}$, albumin $+8.7(95 \% \mathrm{CI}+7 \cdot 2-+10 \cdot 2) \mathrm{g} / \mathrm{l}$. Plasma $\mathrm{Zn}$ concentrations were highly correlated with plasma albumin levels $(\mathrm{Zn}(\mu \mathrm{mol} / \mathrm{l})=3.0+0.21 \times$ albumin $(\mathrm{g} / \mathrm{l}) ; P<0.001)$, and the effect of lactation stage on $\mathrm{Zn}$ disappeared once the data were adjusted for albumin using analysis of covariance $(P=0.54$; mean difference at 52 weeks compared with baseline $-0.1(95 \%$ CI $-1 \cdot 0-+0.8) \mu \mathrm{mol} / 1)$. No correlations were observed between $\alpha_{1}$-antichymotrypsin levels and either plasma $\mathrm{Zn}$, with or without albumin correction, or plasma ferritin concentrations measured at week 13 . Urinary $\mathrm{Mg}$ excretion was not influenced by lactation stage $(P=0 \cdot 26)$.

Within individuals, after adjustment for lactation stage, plasma $\mathrm{Zn}$ concentration varied between the seasons, with hot-season values higher than at other times of year $(P<0.001$; 
Table 3. Effect of season on indices of zinc and magnesium status in lactating Gambian women*

(Values are mean differences and $95 \% \mathrm{CI}$ between seasons, within individuals after adjusting for lactation stage using repeat measures analysis of variance. Further adjustment for albumin was by analysis of covariance. Differences between seasons were obtained using Scheffé post-hoc tests. Data are for sixty women measured four times during lactation)

\begin{tabular}{|c|c|c|c|c|}
\hline Seasonal difference... & Hot - Harvest & Hot - Wet & Wet-Harvest & $\begin{array}{l}\text { Statistical } \\
\text { significance } \\
\text { overall: } P\end{array}$ \\
\hline Plasma Zn $\ddagger(\mu \mathrm{mol} / \mathrm{l})$ & $\begin{array}{c}+1.5 \\
(+0.7-+2 \cdot 3) \\
P<0.001\end{array}$ & $\begin{array}{c}+1.1 \\
(+0.3-+1.9) \\
P=0.013\end{array}$ & $\begin{array}{c}+0 \cdot 4 \\
(-0.4-+1 \cdot 2) \\
\text { NS }\end{array}$ & $<0.001$ \\
\hline Plasma albumin (g/l) & $\begin{array}{c}+2 \cdot 6 \\
(+1 \cdot 1-+4 \cdot 1) \\
P=0.003\end{array}$ & $\begin{array}{c}+4 \cdot 5 \\
(+3 \cdot 1-+5 \cdot 9) \\
P<0-001\end{array}$ & $\begin{array}{c}-1 \cdot 9 \\
(-3 \cdot 5--0 \cdot 3) \\
\text { NS }\end{array}$ & $<0.001$ \\
\hline $\begin{array}{l}\text { Plasma } \mathrm{Zn} \ddagger \text { adjusted for albumin } \\
(\mu \mathrm{mol} / \mathrm{l})\end{array}$ & $\begin{array}{c}+1.1 \\
(+0.4+1 \cdot 8) \\
P=0.008\end{array}$ & $\begin{array}{c}+0-2 \\
(-0.6-+1 \cdot 0) \\
\text { NS }\end{array}$ & $\begin{array}{c}+0.9 \\
(+0.2-+1 \cdot 6) \\
P=0.047\end{array}$ & 0.004 \\
\hline Urinary Mg $\ddagger$ output $(\mathrm{mmol} / \mathrm{d}) \dagger$ & $\begin{array}{c}+6 \cdot 4 \\
(+0.8-+12 \cdot 0) \\
\mathrm{NS}\end{array}$ & $\begin{array}{c}+11 \cdot 5 \\
(+5 \cdot 7-+17 \cdot 3) \\
P<0 \cdot 001\end{array}$ & $\begin{array}{c}-5 \cdot 1 \\
(-11 \cdot 1-+0 \cdot 9) \\
\text { NS }\end{array}$ & $<0.001$ \\
\hline $\begin{array}{l}\text { Urinary Mgt: creatinine } \dagger \\
(\mathrm{mmol} / \mathrm{mmol})\end{array}$ & $\begin{array}{c}+0.15 \\
(+0.07-+0.23) \\
P=0.003\end{array}$ & $\begin{array}{c}+0.17 \\
(+0.09-+0.25) \\
P<0.001\end{array}$ & $\begin{array}{c}-0.02 \\
(-0.12-+0.08) \\
\text { NS }\end{array}$ & $<0.001$ \\
\hline
\end{tabular}

Hot, March-June; Wet, July-October; Harvest, November-February.

* For details of subjects and procedures, see pp. 822-824.

$\dagger$ Urine values are for subjects with creatinine clearance $\geqslant 60 \mathrm{ml} / \mathrm{min}$ per $1.73 \mathrm{~m}^{2}$. Missing data points are as shown in Table 1.

$\ddagger$ To convert $\mathrm{Zn}$ to $\mu \mathrm{g} / \mathrm{l}$ and $\mathrm{Mg}$ to $\mathrm{mg} / \mathrm{l}$ multiply by $65 \cdot 4$ and $24 \cdot 3$ respectively.

Table 3). This was associated in part with seasonal variations in albumin concentration (Table 3). However, after adjusting for albumin using analysis of covariance, a significant effect of season on plasma $\mathrm{Zn}$ concentration remained $(P=0.004)$, with harvest-season values lower than at other times. Urinary $\mathrm{Mg}$ excretion was higher in the hot season than during the rest of the year (Table 3). No seasonal variation in plasma ferritin or $\alpha_{1}-$ antichymotrypsin concentrations was evident. No differences were observed between $S$ and $P$ groups either in absolute values or in the pattern of change across time for any of the indices of mineral status, after statistical adjustment for the possible confounding effects of lactation stage and season (Table 2).

Table 4 compares the indices of mineral status between lactating Gambian and British mothers at 13 weeks postpartum. The Gambian women had a significantly lower plasma $\mathrm{Zn}$ concentration than the British mothers. This was partly accounted for by lower albumin concentration, but a substantial difference in $\mathrm{Zn}$ concentration remained after adjusting for albumin using analysis of covariance (mean difference Gambian-British $-2.7(95 \% \mathrm{CI}$ $-3.9--1.5) \mu \mathrm{mol} / 1, P<0.001)$. The concentration of $\alpha_{1}$-antichymotrypsin was lower in the British women (Table 4) but adjusting for $\alpha_{1}$-antichymotrypsin did not affect the between-country difference in $\mathrm{Zn}$ concentration. There were no significant differences in plasma ferritin or urinary $\mathrm{Mg}$ excretion between women in the two countries. As with the Gambian subjects, a substantial percentage (36) of the British women had plasma ferritin concentrations $<12 \mu \mathrm{g} / 1$ at 13 weeks postpartum.

One Gambian mother had a consistently raised ferritin concentration which exceeded 
Table 4. Comparison between indices of mineral status in lactating Gambian and British mothers at 13 weeks postpartum*

(Mean values and standard deviations, with ranges shown in parentheses for sixty Gambian and fifteen British women)

\begin{tabular}{|c|c|c|c|c|c|}
\hline & \multicolumn{2}{|c|}{ Gambian } & \multicolumn{2}{|c|}{ British } & \multirow{2}{*}{$\begin{array}{c}\text { Statistical } \\
\text { significance } \\
\text { of difference: } P\end{array}$} \\
\hline & Mean & SD & Mean & SD & \\
\hline Plasma Zn† $(\mu \mathrm{mol} / \mathrm{l})$ & \multicolumn{2}{|c|}{$\begin{array}{cc}10 \cdot 3 & 2 \cdot 0 \\
(5 \cdot 2-14 \cdot 8)\end{array}$} & \multicolumn{2}{|c|}{$\begin{array}{cc}13 \cdot 4 & 2 \cdot 3 \\
(10 \cdot 0-17 \cdot 6)\end{array}$} & $<0.001$ \\
\hline Plasma albumin $(\mathrm{g} / \mathrm{l})$ & \multicolumn{2}{|c|}{$\begin{array}{c}37 \cdot 1 \\
(29 \cdot 5-45 \cdot 2)\end{array}$} & \multicolumn{2}{|c|}{$\begin{array}{cc}40-6 & 7 \cdot 1 \\
(28 \cdot 0-49 \cdot 6)\end{array}$} & 0.004 \\
\hline Plasma ferritin $\left(\log _{10} ; \mu \mathrm{g} / \mathrm{l}\right) \ddagger$ & \multicolumn{2}{|c|}{$\begin{array}{l}1.18 \quad 0.40 \\
(0.41-2.24)\end{array}$} & \multicolumn{2}{|c|}{$\begin{array}{l}1.17 \quad 0.33 \\
(0.60-1.73)\end{array}$} & NS (0.92) \\
\hline Plasma $\alpha_{1}$-antichymotrypsin (g/l) & \multicolumn{2}{|c|}{$\begin{array}{l}0.34 \quad 0.06 \\
(0.22-0.56)\end{array}$} & \multicolumn{2}{|c|}{$\begin{array}{ll}0.25 & 0.03 \\
(0.20-0.31)\end{array}$} & $<0.001$ \\
\hline Urinary $\mathrm{Mg} \dagger$ output $(\mathrm{mmol} / \mathrm{d}) \S$ & \multicolumn{2}{|c|}{$\begin{array}{c}31 \cdot 8 \quad 14 \cdot 9 \\
(7 \cdot 1-73 \cdot 7)\end{array}$} & \multicolumn{2}{|c|}{$\begin{array}{c}41 \cdot 1 \quad 11 \cdot 7 \\
(17 \cdot 7-58 \cdot 7)\end{array}$} & NS $(0.06)$ \\
\hline Urinary $\mathrm{Mg} \dagger$ : creatinine $(\mathrm{mmol} / \mathrm{mmol}) \S$ & $\begin{array}{l}0 \cdot 45 \\
(0 \cdot 1\end{array}$ & $\begin{array}{l}0 \cdot 18 \\
56)\end{array}$ & $\begin{array}{l}0 \cdot 37 \\
(0 \cdot 15\end{array}$ & $\begin{array}{l}0.13 \\
05)\end{array}$ & NS $(0 \cdot 13)$ \\
\hline
\end{tabular}

* For details of subjects and procedures, see pp. 822-824.

$\dagger$ To convert $\mathrm{Zn}$ to $\mu \mathrm{g} / \mathrm{l}$ and $\mathrm{Mg}$ to $\mathrm{mg} / \mathrm{l}$ multiply by 65.4 and $24 \cdot 3$ respectively.

$\ddagger$ Geometric mean ferritin concentrations $(\mu \mathrm{g} / 1)$ : Gambian 15·1, British 14.7.

$\S$ Subjects with creatinine clearance $\geqslant 60 \mathrm{ml} / \mathrm{min}$ per $1.73 \mathrm{~m}^{2}$ ( $n 58$ Gambian women, $n 15$ British women).

$150 \mu \mathrm{g} / 1$ at all time points but was not associated with an elevated $\alpha_{1}$-antichymotrypsin concentration. Analysing the data without this subject did not alter the interpretation of results in any way.

\section{DISCUSSION}

Concerns have been raised about the possible detrimental effects of increased Ca intake on the status of other minerals, particularly Fe (NIH Consensus Statement, 1994; Whiting, 1995). An inhibitory effect of $\mathrm{Ca}$ on the absorption of $\mathrm{Fe}$ has been demonstrated in a number of studies (Dawson-Hughes et al. 1986; Cook et al. 1991; Hallberg et al. 1992; Whiting, 1995), an effect which appears to be particularly striking when Ca supplements are consumed with meals (Cook et al. 1991; Whiting, 1995). Effects of $\mathrm{Ca}$ on $\mathrm{Zn}$ and $\mathrm{Mg}$ absorption have also been identified (Wacker \& Vallee, 1964; Ferguson et al. 1989; Argiratos \& Samman, 1994). In spite of these detailed experimental studies, there have been few investigations of the long-term implications of raised $\mathrm{Ca}$ intake on the status of other minerals. Short-term studies, ranging from several days to 3 months, have not identified any effect of $\mathrm{Ca}$ supplementation on $\mathrm{Fe}$ status or $\mathrm{Zn}$ retention (Spencer et al. 1984; Dawson-Hughes et al. 1986; Sokoll \& Dawson-Hughes, 1992). The study of lactating Gambian women presented here has demonstrated that regular ingestion of a $\mathrm{CaCO}_{3}$ supplement for 12 months, consumed between meals, does not result in measurable changes in plasma $\mathrm{Zn}$ concentration, plasma ferritin concentration and urinary $\mathbf{M g}$ excretion.

The supplementation study was designed principally to investigate whether lactating women on low-Ca diets would benefit from an increase in $\mathrm{Ca}$ intake in terms of breast-milk Ca concentration and bone mineral content (Prentice et al. 1995). The sample size ( $n 30$ per group), therefore, was determined by power calculations based on the main outcome variables and was not selected to test whether the $\mathrm{Ca}$ supplementation alters the status of other minerals. However, using calculations based on the data for lactating British women 
at 13 weeks (Table 4 ), the study had the statistical power $(P<0.05$ and $80 \%$ power) to detect differences between the $S$ and $P$ groups of $12 \%$ for plasma $\mathrm{Zn}$ and $20 \%$ for plasma ferritin and urinary $\mathrm{Mg}$ output. Such differences, had they been observed, would have indicated a modest effect of the supplement, similar to the detected changes with season and lactation stage. Smaller effects may have been missed with this sample size, but would have been of minor physiological importance.

The results of the present study are limited by the indices of mineral status chosen for measurement. It is possible, for example, that other factors, homeostatic or environmental, may have influenced the concentrations of plasma ferritin and $\mathrm{Zn}$ and the excretion of $\mathrm{Mg}$, obscuring the effects of the $\mathrm{Ca}$ supplement on other body pools of these minerals. In addition, plasma ferritin is a sensitive measure of residual Fe stores, but is of relatively little value in investigating change in depleted subjects (plasma ferritin concentration $<12 \mu \mathrm{g} / \mathrm{l}$; Fairweather-Tait, 1993). Measurements of circulating transferrin receptor might have been useful in this respect but were not available in the present study. However, analysis of the ferritin data in those Gambian women with plasma ferritin concentrations $\geqslant 12 \mu \mathrm{g} / 1 \mathrm{did}$ not suggest any detrimental effect of the supplement on Fe stores (Table 2).

The $\mathrm{Ca}$ intake of the Gambian women in the present study, in common with other women in this part of Africa, was low compared with international recommendations (Prentice, 1994). The $\mathrm{CaCO}_{3}$ supplement, $25 \mathrm{mmol} / \mathrm{d}(1000 \mathrm{mg} / \mathrm{d})$ taken $5 \mathrm{~d} /$ week, tripled the $\mathrm{Ca}$ intake of these women for over 12 months (Prentice et al. 1995). The Ca supplement was well received, compliance was $100 \%$, and the observed increase in urinary Ca output, reflecting a higher quantity of $\mathrm{Ca}$ absorbed, was in line with the response predicted from other studies (Prentice et al. 1995). In addition, the efficiency of Ca absorption of the Gambian women was high compared with that of the British mothers, as measured by a double-stable-isotope technique (Fairweather-Tait et al. 1995).

The women recruited into the supplementation study were considered to be at high risk of $\mathrm{Fe}$ deficiency, because of the high prevalence of Fe-deficiency anaemia in this population. This proved to be the case, with more than $40 \%$ of the women at 13 weeks postpartum having a plasma ferritin concentration below $12 \mu \mathrm{g} / 1$, the lower limit of the reference range (Fairweather-Tait, 1993). This percentage increased to $50 \%$ by 78 weeks postpartum.

Although the measurement of plasma $\mathrm{Zn}$ concentration has limitations as an index of $\mathrm{Zn}$ status (Aggett \& Favier, 1993), the biochemical results suggested that the Gambian subjects were also at risk of $\mathrm{Zn}$ deficiency, since their plasma $\mathrm{Zn}$ concentration at 13 weeks postpartum was substantially lower than that of the comparative group of lactating British women (by 3.1 and $2.7 \mu \mathrm{mol} / 1$ before and after albumin correction respectively). The mean plasma Zn concentration of the British women, $13.4 \mu \mathrm{mol} / 1$, was similar to published data for breast-feeding mothers in other well-nourished communities (Moser \& Reynolds, 1983; Karra et al. 1988; Krebs et al. 1995). The lower plasma Zn concentration at 9 d postpartum compared with later in lactation has been observed in other groups of women who have recently given birth (Moser \& Reynolds, 1983; Karra et al. 1988; Krebs et al. 1995). In the Gambian women this was accounted for entirely by reduced plasma albumin concentration in the period immediately postpartum.

Assessments of $\mathrm{Zn}$ and $\mathrm{Fe}$ status using plasma $\mathrm{Zn}$ and ferritin concentration are confounded by infection, since both are influenced by the acute-phase response. Plasma $\mathrm{Zn}$ concentration tends to fall, and plasma ferritin concentration to rise, during episodes of infection or inflammation. However, the low concentrations of $\alpha_{1}$-antichymotrypsin, a sensitive acute-phase marker (Calvin et al. 1988), in the plasma samples collected at 13 weeks, and the consistency of plasma ferritin concentrations within individuals over the 18month period, suggest that the results were not affected by episodes of infection. The 
seasonal variations observed in plasma $\mathrm{Zn}$ concentration may have been associated with changes in exposure to infective stress, activity levels and/or diet but, since they occurred in the group as a whole, they are unlikely to have obscured differences between women receiving the $\mathrm{Ca}$ supplement and those receiving the placebo.

International recommendations for optimal Ca nutrition vary, but many include advice to increase $\mathrm{Ca}$ intake during puberty, pregnancy and lactation (Prentice, 1991, 1994). Anxieties about osteoporosis have led to calls for large increases in the recommendations for $\mathrm{Ca}$ intake particularly for adolescents and postmenopausal women (NIH Consensus Statement, 1994). For many, especially for individuals who do not regularly consume milk and dairy products, such high $\mathrm{Ca}$ intakes are not readily achievable by dietary means. $\mathrm{Ca}$ supplements and Ca-fortified foods are becoming increasingly popular as a means to increase $\mathrm{Ca}$ intake. Experts are divided about the optimal timing of Ca supplements, with some arguing that they should be consumed with meals in order to improve efficiency of absorption (Levenson \& Bockman, 1994), while others advocate consumption away from meals to minimize possible adverse interactions with other minerals and trace elements (NIH Consensus Statement, 1994). The present randomized supplementation study of lactating mothers in The Gambia has demonstrated that long-term ingestion of $\mathrm{CaCO}_{3}$ between meals by healthy women at high risk of Fe deficiency, and possibly also of $\mathrm{Zn}$ deficiency, does not influence $\mathrm{Fe}, \mathrm{Zn}$ and $\mathrm{Mg}$ status as assessed by ferritin and $\mathrm{Zn}$ concentrations in plasma and by urinary $\mathrm{Mg}$ excretion.

We are grateful to all the women who participated in this study; to Yankuba Sawo, Sainabou Darboe, Steve Austin and S. Gabrielle Wharf for assistance with the collection and transportation of samples; to Momodou Darboe for $\alpha_{1}$-antichymotrypsin measurements; to Odile Dewit for organizing and holding the randomization code. The study was supported by the Commission of the European Communities, under the Science and Technology for Development Programme Medicine, Health and Nutrition in the Tropics, TS2*.0228.UK(JR). L. Y., from Shenyang Medical College, was a visiting worker at the Dunn Nutrition Unit, funded by a scholarship from the Government of the People's Republic of China.

\section{REFERENCES}

Aggett, P. J. \& Favier, A. (1993). Flair Concerted Action No. 10 Status Papers: Zinc. International Journal for Vitamin and Nutrition Research 63, 301-307.

Argiratos, V. \& Samman, S. (1994). The effect of calcium carbonate and calcium citrate on the absorption of zinc in healthy female subjects. European Journal of Clinical Nutrition 48, 198-204.

Calvin, J., Neale, G., Fotherby, K. J. \& Price, C. P. (1988). The relative merits of acute phase proteins in the recognition of inflammatory conditions. Annals of Clinical Biochemistry 25, 60-66.

Cook, J. D., Dassenko, S. A. \& Whittaker, P. (1991). Calcium supplementation: effect on iron absorption. American Journal of Clinical Nutrition 53, $106-111$.

Data Description Inc. (1993). DataDesk 4.1. Ithaca, NY: Data Description Inc.

Dawson-Hughes, B., Seligson, F. H. \& Hughes, V. A. (1986). Effects of calcium carbonate and hydroxyapatite on zinc and iron retention in postmenopausal women. American Journal of Clinical Nutrition 44, 83-88.

Fairweather-Tait, S. J. (1993). Flair Concerted Action No. 10 Status Papers: Iron. International Journal for Vitamin and Nutrition Research 63, 296-301.

Fairweather-Tait, S. J. (1995). Iron-zinc and calcium-Fe interactions in relation to $\mathrm{Zn}$ and Fe absorption. Proceedings of the Nutrition Society 54, $465-473$.

Fairweather-Tait, S. J., Prentice, A., Heumann, K. G., Jarjou, L. M. A., Stirling, D. M., Wharf, S. G. \& Turnlund, J. R. (1995). Effect of calcium supplements and stage of lactation on the efficiency of absorption of calcium by lactating women accustomed to low calcium intakes. American Journal of Clinical Nutrition 62 , $1188-1192$.

Ferguson, E. L., Gibson, R. S., Thompson, L. U. \& Ounpuu, S. (1989). Dietary calcium, phytate, and zinc intakes and the calcium, phytate, and zinc molar ratios of the diets of a selected group of East African children. American Journal of Clinical Nutrition 50, 1450-1456.

Gossel, T. A. (1991). Calcium supplements. US Pharmacist April issue, 26-32. 
Hallberg, L., Rossander-Hulthén, L., Brune, M. \& Gleerup, A. (1992). Calcium and iron absorption : mechanism of action and nutritional importance. European Journal of Clinical Nutrition 46, 317-327.

Heaney, R. P. (1991). Calcium supplements: practical considerations. Osteoporosis International 1, 65-71.

Karra, M. V., Kirksey, A., Galal, O., Bassily, N. S., Harrison, G. G. \& Jerome, N. W. (1988). Zinc, calcium and magnesium concentrations in milk from American and Egyptian women throughout the first 6 months of lactation. American Journal of Clinical Nutrition 47, 642-648.

Krebs, N. F., Redinger, C. J., Hartley, S., Robertson, A. D. \& Hambidge, K. M. (1995). Zinc supplementation during lactation: effects on maternal status and milk zinc concentrations. American Journal of Clinical Nutrition 61, 1030-1036.

Levenson, D. I. \& Bockman, R. S. (1994). A review of calcium preparations. Nutrition Reviews 52, $221-232$.

Moser, P. B. \& Reynolds, R. D. (1983). Dietary zinc intakes and zinc concentrations of plasma, erythrocytes and breast milk in antepartum and postpartum lactating and nonlactating women: a longitudinal study. American Journal of Clinical Nutrition 38, 101-108.

NIH Consensus Statement (1994). Optimal calcium intake. Journal of the American Medical Association 272. 1942-1948.

Prentice, A. (1991). Functional significance of marginal calcium deficiency. In Modern Lifestyles, Lower Energy Intake and Micronutrient Status, pp. 139-154 [K. Peitrzik, editor]. London: Springer-Verlag.

Prentice, A. (1994). Maternal calcium requirements during pregnancy and lactation. American Journal of Clinical Nutrition 59S, 477-483.

Prentice, A., Jarjou, L. M. A., Cole, T. J., Stirling, D. M., Dibba, B. \& Fairweather-Tait, S. (1995). Calcium requirements of lactating Gambian mothers: effects of a calcium supplement on breast-milk calcium concentration, maternal bone mineral content and urinary calcium excretion. American Journal of Clinical Nutrition 65, 58-67.

Sokoll, L. J. \& Dawson-Hughes, B. (1992). Calcium supplementation and plasma ferritin concentrations in premenopausal women. American Journal of Clinical Nutrition 56, 1045-1048.

Spencer, H., Kramer, L., Norris, C. \& Osis, D. (1984). Effect of calcium and phosphorus on zinc metabolism in man. American Journal of Clinical Nutrition 40, 1213-1218.

Tsang, W. M., Howell, M. J. \& Miller, A. L. (1988). A simple enzymatic method for the measurement of magnesium in serum and urine on a centrifugal analyser. Annals of Clinical Biochemistry 25, 162-168.

Wacker, W. E. C. \& Vallee, B. L. (1964). Magnesium. In Mineral Metabolism: An Advanced Treatise, pp. 483-521 [C. L. Comar and F. Bronner, editors]. New York: Academic Press.

Whiting, S. (1995). The inhibitory effect of dietary calcium on iron bioavailability: a cause for concern? Nutrition Reviews 53, 77-80. 